\title{
Reductive dechlorination of trichloroacetic acid (TCAA) by electrochemical process over $\mathrm{Pd}-\mathrm{In} / \mathrm{Al}_{2} \mathrm{O}_{3}$ catalyst
}

\author{
Yanzhen Liu ${ }^{\mathrm{a}, \mathrm{b}}$, Ran Mao ${ }^{\mathrm{a}}$, Yating Tonga ${ }^{\mathrm{a}}$ Huachun Lan ${ }^{\mathrm{a}, *}$, Gong Zhang ${ }^{\mathrm{a}}$, Huijuan Liu ${ }^{\mathrm{b}, \mathrm{c}}$, \\ Jiuhui $\mathrm{Qu}^{\mathrm{a}, \mathrm{b}}$ \\ ${ }^{a}$ Key Laboratory of Drinking Water Science and Technology, Research Center for Eco-Environmental Sciences, Chinese Academy of Sciences, Beijing, 100085 \\ PR China \\ ${ }^{\mathrm{b}}$ University of Chinese Academy of Sciences, Beijing, 100049, PR China \\ ' State Key Laboratory of Environmental Aquatic Chemistry, Research Center for Eco-Environmental Sciences, Chinese Academy of Sciences, Beijing, 100085, PR \\ China
}

\section{A R T I C L E I N F O}

\section{Article history:}

Received 14 October 2016

Received in revised form 6 February 2017

Accepted 14 February 2017

Available online 16 February 2017

\section{Keywords:}

Electrocatalytic dechlorination

TCAA removal

$\mathrm{Pd}-\mathrm{In} / \gamma-\mathrm{Al}_{2} \mathrm{O}_{3}$

\begin{abstract}
A B S T R A C T
Electrochemical reduction treatment was found to be a promising method for dechlorination of Trichloroacetic acid (TCAA), and acceleration of electron transfer or enhancement of the concentration of atomic $\mathrm{H}^{*}$ significantly improve the electrochemical dechlorination process. Bimetallic Pd-based catalysts have the unique property of simultaneously catalyzing the production of atomic $\mathrm{H}^{*}$ and reducing target pollutants. Herein, a bimetallic Pd-In electrocatalyst with atomic ratio of $1: 1$ was evenly deposited on an $\mathrm{Al}_{2} \mathrm{O}_{3}$ substrate, and the bimetallic Pd-In structure was confirmed via X-ray photoelectron spectroscopy (XPS). Electrochemical removal of trichloroacetic acid (TCAA) by the Pd$\mathrm{In} / \mathrm{Al}_{2} \mathrm{O}_{3}$ catalyst was performed in a three-dimensional reactor. $94 \%$ of TCAA with the initial concentration of $500 \mu \mathrm{g} \mathrm{L}^{-1}$ could be degraded within $30 \mathrm{~min}$ under a relatively low current density $\left(0.9 \mathrm{~mA} \mathrm{~cm}^{-2}\right)$. In contrast to the presence of refractory intermediates (dichloroacetic acid (DCAA)) found in the $\mathrm{Pd} / \mathrm{Al}_{2} \mathrm{O}_{3}$ system, TCAA could be thoroughly reduced to monochloroacetic acid (MCAA) using Pd-In/ $\mathrm{Al}_{2} \mathrm{O}_{3}$ catalysts. According to scavenger experiments, an electron transfer process and atomic $\mathrm{H}^{*}$ formation function both existed in the TCAA reduction process, and the enhanced indirect atomic $\mathrm{H}^{*}$ reduction process (confirmed by ESR signals) played a chief role in the TCAA removal. Moreover, the synergistic effects of $\mathrm{Pd}$ and In were proven to be able to enhance both direct electron transfer and indirect atomic $\mathrm{H}^{*}$ formation, indicating a promising prospect for bimetallic electrochemical reduction treatment.
\end{abstract}

(c) 2017 Elsevier Ltd. All rights reserved.

\section{Introduction}

Trichloroacetic acid (TCAA) is one of the largest fractions of chloroacetic acids (CAAs) that always exists in chlorinated water [1-3]. TCAA has been proven to be carcinogenic and poses potential risks to human health [4,5], and a $0.1 \mathrm{mg} / \mathrm{L}$ standard for TCAA in drinking water has already been promulgated. To meet this limitation, numerous treatment methods, including biodegradation, photocatalysis, advanced oxidation, and Fenton reaction, have recently been explored [6-8]. Among these removal approaches, catalytic hydrogenation has been proven to be an efficient method to remove TCAA [9]. Zhou et al. [10] found that CAAs could be

\footnotetext{
* Corresponding author.

E-mail address: lhclan@126.com (H. Lan).
}

completely dechlorinated to acetic acid over supported $\mathrm{Pd}$ catalysts on $\mathrm{ZrO}_{2}$, which could convert $\mathrm{H}_{2}$ to atomic $\mathrm{H}^{*}$. However, liquid-phase catalytic hydrogenation requires constant $\mathrm{H}_{2}$ supplementation, causing hidden danger for storage and transportation. Alternatively, the electrochemical treatment of TCAA was found to be more promising as it ensures the selective removal of chlorine atoms from TCAA, while no toxic byproducts are produced [11-14]. Two main steps, namely, direct dechlorination by electron transfer and an indirect process induced by atomic $\mathrm{H}^{*}$, take place during the electrocatalytic reduction process [15]. Generally, in contrast to the low reduction efficiency of electron transfer, the catalytically produced atomic $\mathrm{H}^{*}$ plays a predominant role in dechlorination. $\mathrm{Li}$ et al. [13] studied the electrochemical dechlorination activity of CAAs with electrodeposited Fe- and Pd/Fe-modified carbon paper as cathodes. The results showed that while only $58 \%$ of TCAA could be removed within $30 \mathrm{~min}$ at $\mathrm{pH} 7.0$ with the bias potential of 
$-1.5 \mathrm{~V}$ using a Fe-C electrode through the direct electron transfer process, $96 \%$ of TCAA could be removed using a $\mathrm{Pd} / \mathrm{Fe}-\mathrm{C}$ electrode under the same experimental conditions where atomic $\mathrm{H}^{*}$ were formed. Thus, the fabrication of suitable catalysts that can produce higher amounts of atomic $\mathrm{H}^{*}$ has great potential for practical applications.

Palladium catalysts have been proven to have the unique property of activating $\mathrm{H}_{2}$ and catalyzing the electrochemical reduction of $\mathrm{H}^{+}$or $\mathrm{H}_{2} \mathrm{O}$ to produce adsorbed atomic $\mathrm{H}^{*}$, which is a much stronger reducing agent than $\mathrm{H}_{2}$ in catalytic reduction reactions [16]. Some studies found that coupling two metals with different oxidizing abilities could enhance the generation of electrons [17], and some chemical reactions were reported to show better activity and selectivity when using bimetallic and trimetallic catalysts compared with monometallic Pd catalysts [18-20]. The chemical environment of Pd could be modified by a second metal addition [21,22], and the second metal, such as $\mathrm{Au}, \mathrm{Cu}, \mathrm{Bi}, \mathrm{Sn}$ etc. [18-20,23], acts as a promoter for the Pd-based catalysts. For instance, the polymer-protected $\mathrm{Au} / \mathrm{Pd}$ bimetal alloy, with an $\mathrm{Au}$ core structure, exhibited a higher catalytic activity for selective hydrogenation of 1,3-cyclooctadiene than that of monometallic Au or Pd catalyst [20]. In addition, the reduction efficiency of nitrates by $\mathrm{Pd} / \mathrm{SnO}_{2}$ was greatly enhanced after Sn addition [24]. Notably, nitrates and $\mathrm{N}$-Nitrosodimethylamine could be effectively removed after indium was added to $\mathrm{Pd} / \mathrm{Al}_{2} \mathrm{O}_{3}$, owing to the formation of Pd-In intermetallic compounds $[25,26]$. However, studies on the electrochemical reduction of TCAA by Pd-In suspended electrodes are still rare.

In this study, Pd-In mixtures with different atomic ratios were evenly deposited on $\mathrm{Al}_{2} \mathrm{O}_{3}$ substrates via coprecipitation followed by $\mathrm{H}_{2}$ reduction, and their reduction efficiency toward TCAA was evaluated in a three-dimensional electrochemical reactor having better electroreduction efficiency compared to the particle-free system. TEM, XRD, XPS, BET and Zeta potential analysis were carried out to study the synergistic effect between Pd and In. Then, the effects of applied current density, catalyst dosage, initial TCAA concentration and solution $\mathrm{pH}$ on TCAA reduction over $\mathrm{Pd}-\mathrm{In} / \mathrm{Al}_{2} \mathrm{O}_{3}$ were also studied in detail. Moreover, scavenger and DO impact experiments on the TCAA direct electron transfer and indirect atomic $\mathrm{H}^{*}$ process were studied. On the basis of the experimental results, we proposed a reaction mechanism for TCAA reduction using $\mathrm{Pd}-\mathrm{In} / \mathrm{Al}_{2} \mathrm{O}_{3}$.

\section{Materials and methods}

\subsection{Preparation of $\mathrm{Pd}-\mathrm{In} / \mathrm{Al}_{2} \mathrm{O}_{3}$ particle electrodes}

The particle electrodes were prepared by a coprecipitation method. $\gamma-\mathrm{Al}_{2} \mathrm{O}_{3}$ was immersed in a $0.1 \mathrm{M}$ hydrochloric acid solution containing a certain content of $\mathrm{PdCl}_{2}$ and $\mathrm{InCl}_{3} \cdot 4 \mathrm{H}_{2} \mathrm{O}$, then the mixture was ultrasonically treated ( $360 \mathrm{~min}$ ) and left to stand overnight. After drying at $120^{\circ} \mathrm{C}$, the obtained samples were further calcined at $300^{\circ} \mathrm{C}(120 \mathrm{~min})$, followed by reduction in $\mathrm{H}_{2}$ atmosphere $\left(200^{\circ} \mathrm{C} ; 300 \mathrm{~min} ; 100 \mathrm{~mL} / \mathrm{min}\right.$ flow rate). For all the catalysts, the initial palladium loading amount was $3 \mathrm{wt}$ \%, and the final obtained Pd-In catalyst with the initial palladium-to-indium atomic ratio of $1: 1$ was denoted as $\mathrm{Pd}-\mathrm{In} / \mathrm{Al}_{2} \mathrm{O}_{3}$, while others were recorded as $\mathrm{Pd}_{\mathrm{x}}-\mathrm{In}_{\mathrm{y}} / \mathrm{Al}_{2} \mathrm{O}_{3}$ (x: y refers to palladium-to-indium ratio). $\mathrm{Pd} / \mathrm{Al}_{2} \mathrm{O}_{3}$ and $\mathrm{In} / \mathrm{Al}_{2} \mathrm{O}_{3}$ with $3 \mathrm{wt}$. \% metal loading amounts were also prepared under the same conditions.

\subsection{Particle electrode characterization}

X-ray powder diffraction (XRD) patterns were measured using

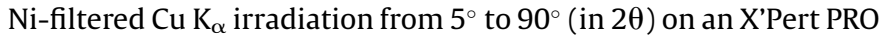
Powder diffractometer (PANalytical Co.). Transmission Electron
Microscope (TEM) images and Energy Dispersive Spectrometer (EDS) images were obtained with a Transmission Electron Microscope (JEM-2100F Field Emission Electron Microscope, JEOL Ltd.). The specific surface area (BET), pore diameter, and pore volume were measured by the nitrogen adsorption method with a surface area analyzer, model ASAP 2020 HD88 (Micromeritics Co.). Surface potential was characterized with a Nano Particle Sizing \& Zeta Potential Analyzer (DelsaNano C, Beckman Coulter Ltd.). The $\mathrm{X}$-ray photoelectron spectroscopy (XPS) data for particle electrodes were collected with a PHI Quantera SXM ${ }^{\mathrm{TM}}$ Scanning X-ray Microprobe $^{\mathrm{TM}}$ ( $\Phi$ ULVAC-PHI. INC.).

\subsection{Three-dimensional electrochemical reactor and batch experiment}

The electrochemical dechlorination of TCAA by Pd-In $/ \mathrm{Al}_{2} \mathrm{O}_{3}$ was carried out in a three-dimensional electrochemical batch reactor, where a proton-exchange membrane (Nafion 117, Dupont) divided the reactor into a cathode cell and anode cell. A $50 \mathrm{~mL}$ aqueous solution composed of a certain content of TCAA $(500 \mu \mathrm{g} / \mathrm{L}$, unless otherwise specified) was added to the cathode cell, and $50 \mathrm{~mL}$ $\mathrm{Na}_{2} \mathrm{SO}_{4}$ solution $(2 \mathrm{mM})$ was added into the anode cell correspondingly. Solution $\mathrm{pH}$ was adjusted with diluted $\mathrm{H}_{2} \mathrm{SO}_{4}$ and $\mathrm{NaOH}$ solutions (guaranteed grade) before each batch experiment. $0.9 \mathrm{~mA} / \mathrm{cm}^{2}$ current density (with a $6.8 \mathrm{~V}$ potential) was applied to the reactor which was powered by a DC power supply source (AMERLLPS302A, Dahua instrument corporation of Beijing). $\mathrm{RuO}_{2} /$ Ti electrodes with the same effective geometric surface area $\left(10 \mathrm{~cm}^{2}\right)$ and $2 \mathrm{~cm}$ separation were employed as the cathode and anode, and a certain quantity of $\mathrm{Pd}_{\mathrm{x}}-\mathrm{In}_{\mathrm{y}} / \mathrm{Al}_{2} \mathrm{O}_{3}(1.0 \mathrm{~g} / \mathrm{L}$ unless emphasized) was added into the cathode cell as the particle electrode (stirring rate: $800 \mathrm{rpm}$, room temperature). Pure Nitrogen/oxygen was purged to modify the DO concentration $(0.2$ and $30 \mathrm{mg} / \mathrm{L}, 7.42 \mathrm{mg} / \mathrm{L}$ "air saturated solution"). Heating bath method was applied to control the reaction temperature $(303.15 \mathrm{~K}$ and $273.15 \mathrm{~K}$, room temperature ranged from 288.15 to $291.15 \mathrm{~K}$ ).

\subsection{Analysis method}

The concentrations of TCAA, dichloroacetic acid (DCAA) and monochloroacetic acid (MCAA) were measured by an ion chromatograph (IC) (Dionex 2000) equipped with an IonPac AS19 anion-exchange analytical column and an IonPac AG19 guard column. The mobile phase eluent of the IC was $\mathrm{KOH}$ solution. The chromatograms of TCAA, DCAA and MCAA were collected under gradient elution conditions (0.0-30.0 min: $10.0 \mathrm{mM} \mathrm{KOH}$; 30.1 $37.0 \mathrm{~min}: 35.0 \mathrm{mM} \mathrm{KOH}$; $37.1-43.0 \mathrm{~min}: 10.0 \mathrm{mM} \mathrm{KOH}$, flow rate: $1.0 \mathrm{~mL} / \mathrm{min}$ ).

Atomic $\mathrm{H}^{*}$ was trapped by $5,5^{\prime}$-dimethyl-1-pirroline-N-oxide (DMPO), and the signals were further detected by a Bruker model $300 \mathrm{E}$ electron spin resonance (ESR) spectrometer, using a quantaRay Nd:YAG laser system for the irradiation source.

\section{Results and discussion}

\subsection{Characterization of $\mathrm{Pd}-\mathrm{In} / \gamma-\mathrm{Al}_{2} \mathrm{O}_{3}$ particle electrodes}

As shown in Fig. 1(a), diffraction peaks at $40.1^{\circ}, 46.7^{\circ}$ and $68.1^{\circ}$ assigned to the face centered cubic (fcc) crystallographic structure of metallic Pd were observed for the $\mathrm{Pd} / \mathrm{Al}_{2} \mathrm{O}_{3}$ catalyst [27,28], and the peak at $40.1^{\circ}$ shifts slightly to lower angle at $39.2^{\circ}$ for Pd-In/ $\mathrm{Al}_{2} \mathrm{O}_{3}$ catalysts, related to the formation of the Pd-In bimetallic alloy [29]. The dark spots in the TEM picture (Fig. 1(b)) were denoted as Pd or In particles with atomic numbers. Though it was difficult to distinguish whether the Pd, In particles was just located between the $\mathrm{Al}_{2} \mathrm{O}_{3}$ multi-layers or scattered in the inner channels of $\mathrm{Al}_{2} \mathrm{O}_{3}$, the EDS images (Fig. 1(c)) indicated that Pd and In 

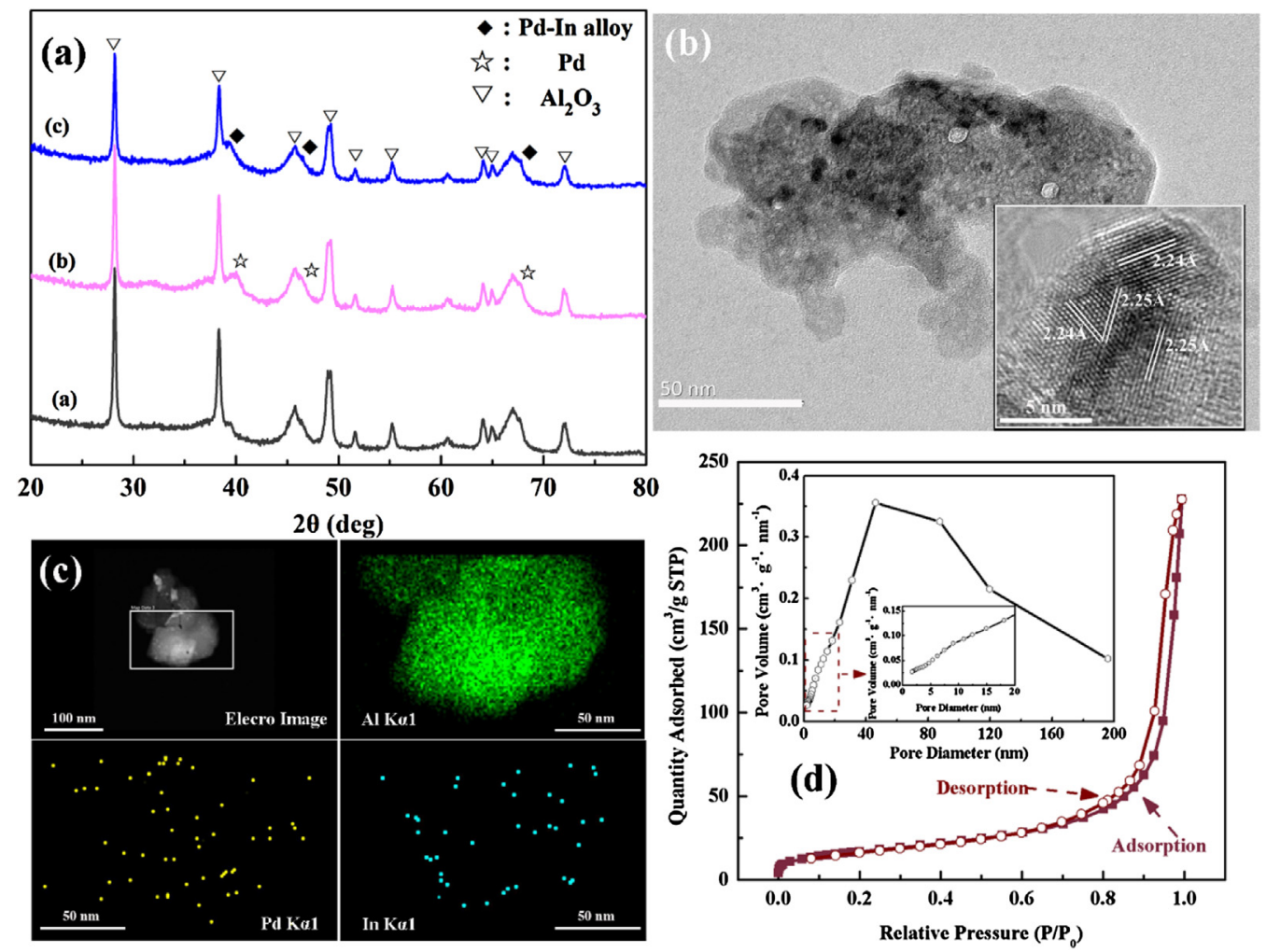

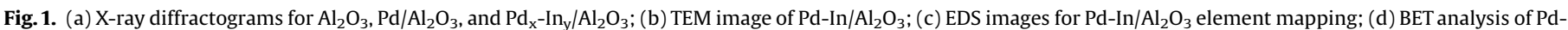
$\mathrm{In} / \mathrm{Al}_{2} \mathrm{O}_{3}$.

particles were dispersed uniformly on the surface of $\mathrm{Al}_{2} \mathrm{O}_{3}$. As shown in inset Fig. 1(b), a distinct lattice structure with a lattice spacing around $2.2 \AA$ was observed, which may derive from the (111) plane of the Pd-In bimetallic alloy (the lattice spacings for Pd and In are $2.2458 \AA$ [27] and $2.25680 \AA \AA$ [30] respectively); besides, some of In particles cover the same sites as Pd particles (shown in Fig. S1), further confirmed the potential of Pd-In alloy formation. BET analyses of the catalysts are listed in Table S1. The specific surface area of the catalysts decreases with increasing Pd-In loading amount, while the pore diameter increases correspondingly. The pore volume of $\mathrm{Al}_{2} \mathrm{O}_{3}$ and $\mathrm{Pd}-\mathrm{In} / \mathrm{Al}_{2} \mathrm{O}_{3}$ were both around $0.3 \mathrm{~cm}^{3} / \mathrm{g}$, it was reasonable to speculate that the decreased specific surface area $\left(71.61 \mathrm{vs} 60.77 \mathrm{~m}^{2} / \mathrm{g}\right)$ was probably resulted from the increased pore diameter (from 16.72 to $23.16 \mathrm{~nm}$ ). The increased pore diameter in the $\mathrm{Al}_{2} \mathrm{O}_{3}$ substrate had much more opportunities to be entered by those nano-seized metallic Pd and
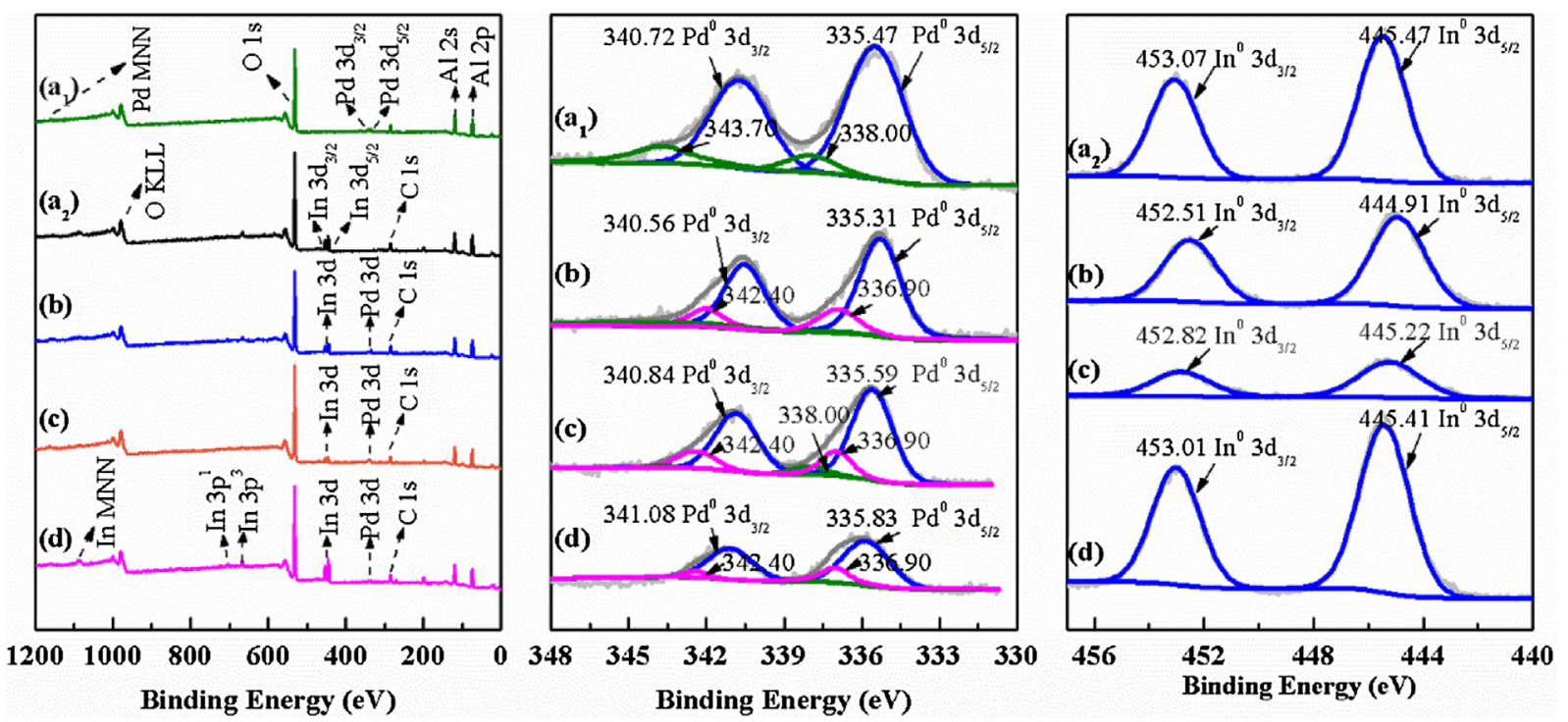

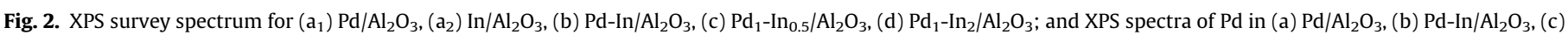
$\mathrm{Pd}_{1}-\mathrm{In}_{0.5} / \mathrm{Al}_{2} \mathrm{O}_{3}$, (d) $\mathrm{Pd}_{1}-\mathrm{In}_{2} / \mathrm{Al}_{2} \mathrm{O}_{3}$; and XPS spectra of In in (a) In $/ \mathrm{Al}_{2} \mathrm{O}_{3}$, (b) Pd-In/ $/ \mathrm{Al}_{2} \mathrm{O}_{3}$, (c) $\mathrm{Pd}_{1}-\mathrm{In}_{0.5} / \mathrm{Al}_{2} \mathrm{O}_{3}$, (d) $\mathrm{Pd}_{1}-\mathrm{In}_{2} / \mathrm{Al}_{2} \mathrm{O}_{3}$. 
In, so that the inner channels were readily to be blocked, decreasing in the specific surface area of the catalysts. As shown in Fig. 1(d), $\mathrm{Pd}-\mathrm{In} / \mathrm{Al}_{2} \mathrm{O}_{3}$ has a mesoporous structure with $60.77 \mathrm{~m}^{2} /$ $\mathrm{g}$ BET area and $17.56 \mathrm{~nm}$ average pore size, giving a type-IV isotherm with a type-H3 loop.

In addition, XPS analyses were carried out to study the influence of In introduction on the Pd valence state, and calibration of XPS spectra was performed referencing to $\mathrm{C} 1 \mathrm{~s}$ peak at $284.8 \mathrm{eV}$ from the adventitious carbon. As shown in Fig. 2, Pd and In were detected in all the Pd-In catalysts. The Pd 3d spectra exhibit a spinorbit doublet at $335.47 \mathrm{eV}\left(3 \mathrm{~d}_{5 / 2}\right)$ and $340.72 \mathrm{eV}\left(3 \mathrm{~d}_{3 / 2}\right)$, indicting the formation of metallic $\mathrm{Pd}$ in $\mathrm{Pd} / \mathrm{Al}_{2} \mathrm{O}_{3}$ [31]; Compared with the $\mathrm{Pd} / \mathrm{Al}_{2} \mathrm{O}_{3}$ catalyst, the $\mathrm{Pd} 3 \mathrm{~d}_{5 / 2}$ spectrum shifted towards a lower value $(335.31 \mathrm{eV})$ for $\mathrm{Pd}-\mathrm{In} / \mathrm{Al}_{2} \mathrm{O}_{3}$, while an opposite shift was observed for $\mathrm{Pd}_{1}-\mathrm{In}_{0.5} / \mathrm{Al}_{2} \mathrm{O}_{3}$ and $\mathrm{Pd}_{1}-\mathrm{In}_{2} / \mathrm{Al}_{2} \mathrm{O}_{3}$. The low binding energy of the $\mathrm{Pd} 3 \mathrm{~d}_{5 / 2}$ peaks for the $\mathrm{Pd}-\mathrm{In} / \mathrm{Al}_{2} \mathrm{O}_{3}$ catalyst indicated that metallic Pd existed in a more electron-rich state, which was beneficial for atomic $\mathrm{H}^{*}$ formation; meanwhile, a decrease in the indium $3 \mathrm{~d}_{5 / 2}$ binding energy was detected, indicating that a Pd-In bimetallic alloy was formed in the $\mathrm{Pd}-\mathrm{In} / \mathrm{Al}_{2} \mathrm{O}_{3}$ catalysts $[32,33]$. Moreover, the $\mathrm{PdCl}_{2}$ remaining in $\mathrm{Pd} / \mathrm{Al}_{2} \mathrm{O}_{3}$ changed into $\mathrm{PdO}$ for all the $\mathrm{Pd}-\mathrm{In} / \mathrm{Al}_{2} \mathrm{O}_{3}$ catalysts, showing that In could change the chemical environment of Pd [34].

\subsection{Efficient electroreduction of TCAA by Pd-In/ $/ \mathrm{Al}_{2} \mathrm{O}_{3}$ with different In to $P d$ atomic ratios}

As the amount of the promoter metal would greatly influence the activity of Pd-based bimetallic catalysts [35], the effect of the In to Pd atomic ratio on TCAA electroreduction was optimized first. As shown in Fig. 3(a), the removal efficiency of TCAA by Pd-based catalysts was increased to a maximum value, and then decreased with increasing atomic ratio of In to Pd. While $\mathrm{In} / \mathrm{Al}_{2} \mathrm{O}_{3}$ showed almost no activity for TCAA reduction, 94\% of TCAA could be reduced in $30 \mathrm{~min}$ by $\mathrm{Pd}-\mathrm{In} / \mathrm{Al}_{2} \mathrm{O}_{3}$, which had the highest electrochemical activity towards TCAA removal. All the reduction processes were shown to follow pseudo-first order kinetics. The reaction rate constants of the catalysts followed the order In/ $\mathrm{Al}_{2} \mathrm{O}_{3}<\mathrm{Pd}_{1}-\mathrm{In}_{2} / \mathrm{Al}_{2} \mathrm{O}_{3}<\mathrm{Pd} / \mathrm{Al}_{2} \mathrm{O}_{3}<\mathrm{Pd}_{1}-\mathrm{In}_{0.5} / \mathrm{Al}_{2} \mathrm{O}_{3}<\mathrm{Pd}-\mathrm{In} / \mathrm{Al}_{2} \mathrm{O}_{3}$, and the catalyst activity increased from 114.29, 672.28, 839.33, 840.28 to $931.34 \mu \mathrm{g} \mathrm{gCat}^{-1} \mathrm{~h}^{-1}$ respectively, as shown in Fig. 3(b). This result indicated that the reduction ability of Pd-based catalysts could be enhanced by adding a proper amount of In, while excess addition of In would restrain the catalyst activity. As In itself did not have the ability for TCAA reduction, an excessive In concentration would decrease the isolated Pd sites [36] and block the channels of the $\mathrm{Al}_{2} \mathrm{O}_{3}$ substrate (confirmed by BET analysis), thus reducing the TCAA removal efficiency.

The reduction products of TCAA over different particle electrodes were further studied. As shown in Fig. 4, 40.0\% of TCAA could be reduced to DCAA in 30 min without using any catalysts. The TCAA reduction efficiency increased to $67.0 \%, 84.0 \%$ and $93.2 \%$ after addition of $\mathrm{Al}_{2} \mathrm{O}_{3}, \mathrm{Pd} / \mathrm{Al}_{2} \mathrm{O}_{3}$ and $\mathrm{Pd}-\mathrm{In} / \mathrm{Al}_{2} \mathrm{O}_{3}$ particle electrodes respectively. Notably, MCAA was detected during the electrochemical process when $\mathrm{Pd}-\mathrm{In} / \mathrm{Al}_{2} \mathrm{O}_{3}$ was used as the particle electrode, and around 42\% DCAA and 16\% TCAA were detected in the $30 \mathrm{~min}$ batch experiment. However, no MCAA was formed when using $\mathrm{Al}_{2} \mathrm{O}_{3}$ or $\mathrm{Pd} / \mathrm{Al}_{2} \mathrm{O}_{3}$ under the same experimental conditions. As In/ $\mathrm{Al}_{2} \mathrm{O}_{3}$ had no effect on TCAA reduction (Fig. 3), we could reasonably infer that In acts as a "promoter" metal for Pd-based catalysts $[25,37]$ and the $1: 1$ initial Pd to In atomic ratio produces the most pronounced synergistic effect between metallic Pd and In on TCAA electroreduction. According to the XPS analysis, metallic Pd existed in a more electron-rich state for $\mathrm{Pd}-\mathrm{In} / \mathrm{Al}_{2} \mathrm{O}_{3}$ than in the other catalysts due to the modification by In, and the electron-rich state was beneficial for atomic $\mathrm{H}^{*}$ formation. So, $\mathrm{Pd}-\mathrm{In} / \mathrm{Al}_{2} \mathrm{O}_{3}$ was shown to be a promising catalyst for the electrochemical removal of TCAA.

\subsection{Effect of different parameters on electrochemical removal of TCAA by $\mathrm{Pd}-\mathrm{In} / \mathrm{Al}_{2} \mathrm{O}_{3}$}

The influences of current density, catalyst dosage, initial concentration, solution $\mathrm{pH}$ and dissolved oxygen (DO) on the electrochemical reduction of $\mathrm{Pd}-\mathrm{In} / \mathrm{Al}_{2} \mathrm{O}_{3}$ were further investigated. As shown in Fig. 5(a), the TCAA removal rate increased greatly with the current density from 0.3 to $0.9 \mathrm{~mA} / \mathrm{cm}^{2}$, and then increased slightly when the current density further increased to $1.2 \mathrm{~mA} / \mathrm{cm}^{2}$. With the increase of current density, more electrons were available for $\mathrm{H}^{*}$ formation and TCAA reduction [38], thus enhancing the TCAA removal efficiency. However, the removal efficiency of TCAA did not change much in the first ten minutes when the current density rose above $0.9 \mathrm{~mA} / \mathrm{cm}^{2}$. This can be explained by the formation of profuse hydrogen bubbles at the electrode surface. Although the presence of bubbles did not damage the electrode, they could still interfere with TCAA diffusion to the catalyst [39]. In addition, as active Pd-In sites are vital for
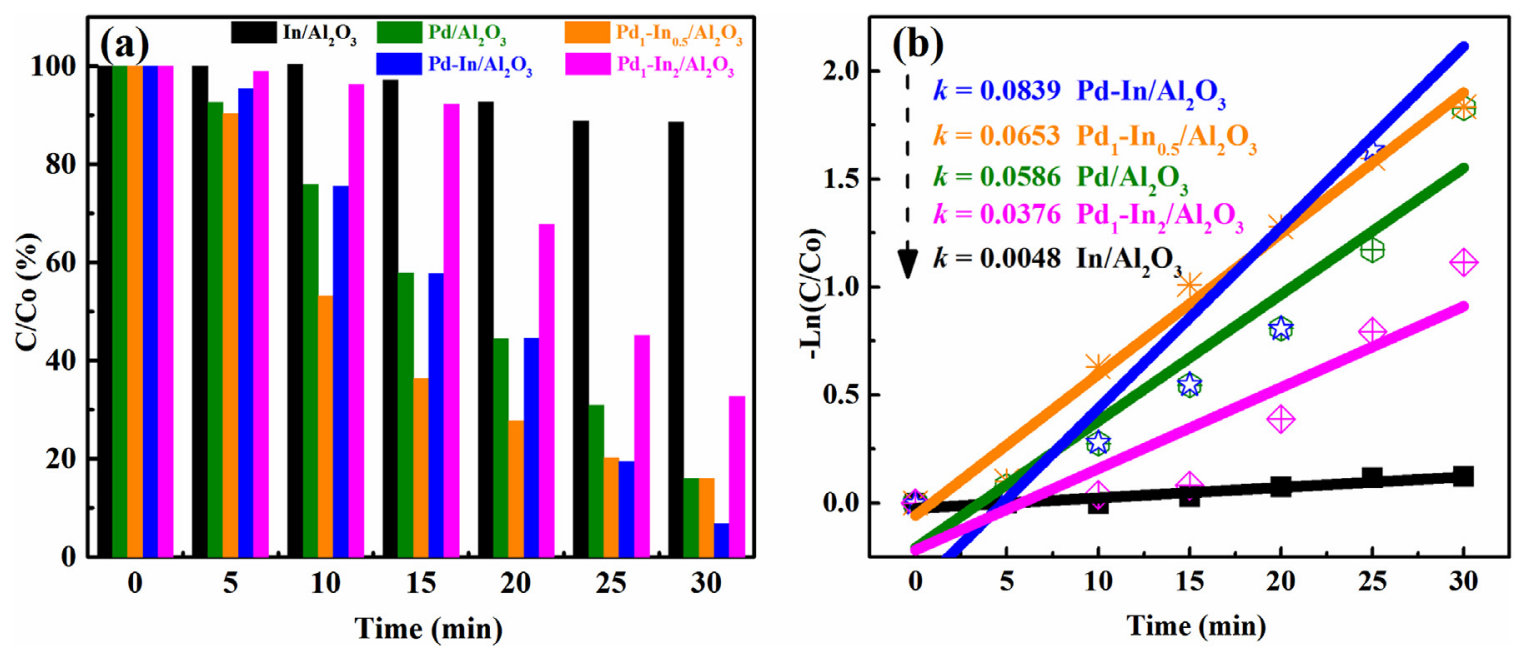

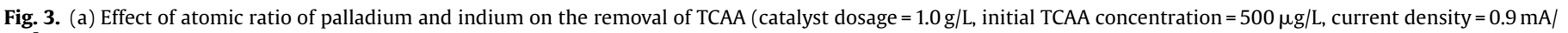
$\mathrm{cm}^{2}$, initial $\mathrm{pH}=7.0,2 \mathrm{mM} \mathrm{Na}_{2} \mathrm{SO}_{4}$, room temperature); (b) the pseudo-first-order kinetics equations of the catalysts. 

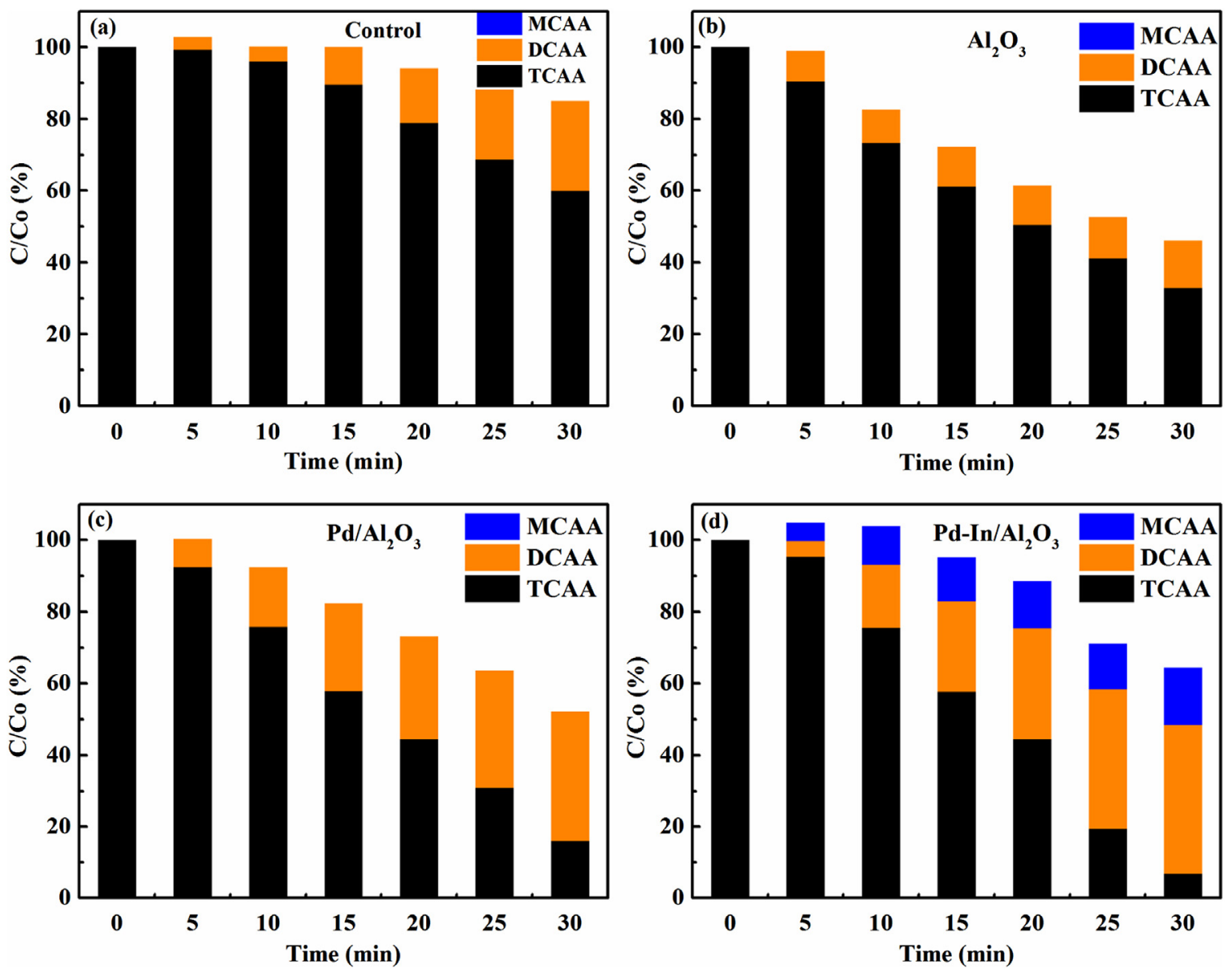

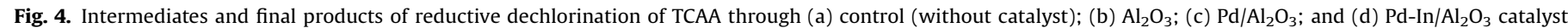
(catalyst dosage $=1.0 \mathrm{~g} / \mathrm{L}$, initial TCAA concentration $=500 \mu \mathrm{g} / \mathrm{L}$, current density $=0.9 \mathrm{~mA} / \mathrm{cm}^{2}$, initial $\mathrm{pH}=7.0,2 \mathrm{mM} \mathrm{Na} \mathrm{SO}_{4}$, room temperature).

TCAA removal [40], the TCAA electrochemical removal rate was observed to increase gradually as the $\mathrm{Pd}-\mathrm{In} / \mathrm{Al}_{2} \mathrm{O}_{3}$ dosage increased from $0.2 \mathrm{~g} / \mathrm{L}$ to $1.0 \mathrm{~g} / \mathrm{L}$ (Fig. 5(b)), and the removal rate achieved a relatively stable value when more catalyst $(1.5 \mathrm{~g} / \mathrm{L})$ was used, where the current density restricted the further enhancement of TCAA reduction.

Moreover, the catalytic activity of $\mathrm{Pd}-\mathrm{In} / \mathrm{Al}_{2} \mathrm{O}_{3}$ catalysts for TCAA removal was more than doubled when the initial TCAA concentration increased from 200 to $500 \mu \mathrm{g} / \mathrm{L}$ (298.9, 451.5, 544.4 and $752.9 \mu \mathrm{g} \mathrm{gCat}^{-1} \mathrm{~h}^{-1}$ for TCAA with the initial concentration of $200,300,400$ and $500 \mu \mathrm{g} / \mathrm{L}$, Fig. S2), attributed to the positive correlation between the TCAA removal rate and the surface coverage of adsorbed TCAA [41]. The corresponding pseudo-first order kinetics reaction rate constant increased gradually from $0.0540,0.0550$, and 0.0561 to $0.0613 \mathrm{~min}^{-1}$.

Furthermore, the effect of initial solution $\mathrm{pH}$ on TCAA removal was not significant, and the pseudo-first order kinetics reaction rate constant of $\mathrm{Pd}-\mathrm{In} / \mathrm{Al}_{2} \mathrm{O}_{3}$ for 20 min of reaction was $0.04 \mathrm{~min}^{-1}$ at all studied pH values from 3.0 to 9.0 (Fig. S3). As shown in Fig. S4, the $\mathrm{Pd}-\mathrm{In} / \mathrm{Al}_{2} \mathrm{O}_{3}$ catalyst was positively charged when $\mathrm{pH}$ was lower than 9.0 and the surface zeta potential changed only slightly when $\mathrm{pH}$ ranged from 3.0 to 9.0. Therefore, the adsorption of TCAA would not change much with changing $\mathrm{pH}$, weaken the impact of the $\mathrm{pH}$ influence. As more than $80 \%$ of TCAA was removed after reaction for $30 \mathrm{~min}$, TCAA could be effectively removed by Pd-In/ $\mathrm{Al}_{2} \mathrm{O}_{3}$ over a wide $\mathrm{pH}$ range.

The effect of temperature to TCAA removal efficiency was further investigated. As shown in Fig. S5, 80.28\%, 94.01\% and $95.23 \%$ of TCAA could be reduced within $30 \mathrm{~min}$ under 273.15 ,
289.15 (room temperature) and $303.15 \mathrm{~K}$ respectively, exhibiting a positive correlation to the temperatures.

In addition, as DO is a ubiquitous kind of oxidant that can compete with TCAA in consuming reducing agents such as electrons and atomic $\mathrm{H}^{*}$, thus suppressing the removal efficiency of TCAA [42], the electrochemical reduction of TCAA by Pd-In/ $\mathrm{Al}_{2} \mathrm{O}_{3}$ was also investigated as a function of DO content. As shown in Fig. 5(d), the TCAA reduction efficiency was highly dependent on the DO content. When the DO concentration was reduced from 7.42 to less than $0.20 \mathrm{mg} / \mathrm{L}$, the TCAA concentration decreased sharply in the first $5 \mathrm{~min}$ and was totally removed in just $15 \mathrm{~min}$, and the reaction constant increased 6 -fold compared to that in the presence of DO of $7.42 \mathrm{mg} / \mathrm{L}$. Comparatively, when the DO content was above $30 \mathrm{mg} / \mathrm{L}$, almost no TCAA was removed in the $30 \mathrm{~min}$ batch experiment, while the reaction constant decreased 31 -fold compared to that with the DO concentration of $7.42 \mathrm{mg} / \mathrm{L}(0.5802$, 0.0026 and $0.0839 \mathrm{~min}^{-1}$ for DO concentrations of $0.20,7.42$ and $30 \mathrm{mg} / \mathrm{L}$ respectively). That is to say, DO is a strong competitor for TCAA in this three-dimensional electrochemical reactor.

As the important indicator for the efficient catalyst, the reusability of $\mathrm{Pd}-\mathrm{In} / \mathrm{Al}_{2} \mathrm{O}_{3}$ was also evaluated. The used $\mathrm{Pd}-\mathrm{In} /$ $\mathrm{Al}_{2} \mathrm{O}_{3}$ catalysts was recovered by centrifuging followed by drying at $80^{\circ} \mathrm{C}$. After reduction in $\mathrm{H}_{2}$ atmosphere at $200^{\circ} \mathrm{C}$ for $300 \mathrm{~min}$, the regenerated $\mathrm{Pd}-\mathrm{In} / \mathrm{Al}_{2} \mathrm{O}_{3}$ was applied to reduce TCAA. After three cycles, more than $80 \%$ of TCAA with the initial concentration of $0.5 \mathrm{mg} / \mathrm{L}$ could be reduced in $30 \mathrm{~min}$, so that the TCAA was decreased below the standard $(0.1 \mathrm{mg} / \mathrm{L})$ (Fig. S6). The stability of $\mathrm{Pd}-\mathrm{In} / \mathrm{Al}_{2} \mathrm{O}_{3}$ is essential for reducing the cost in the practical applications. 

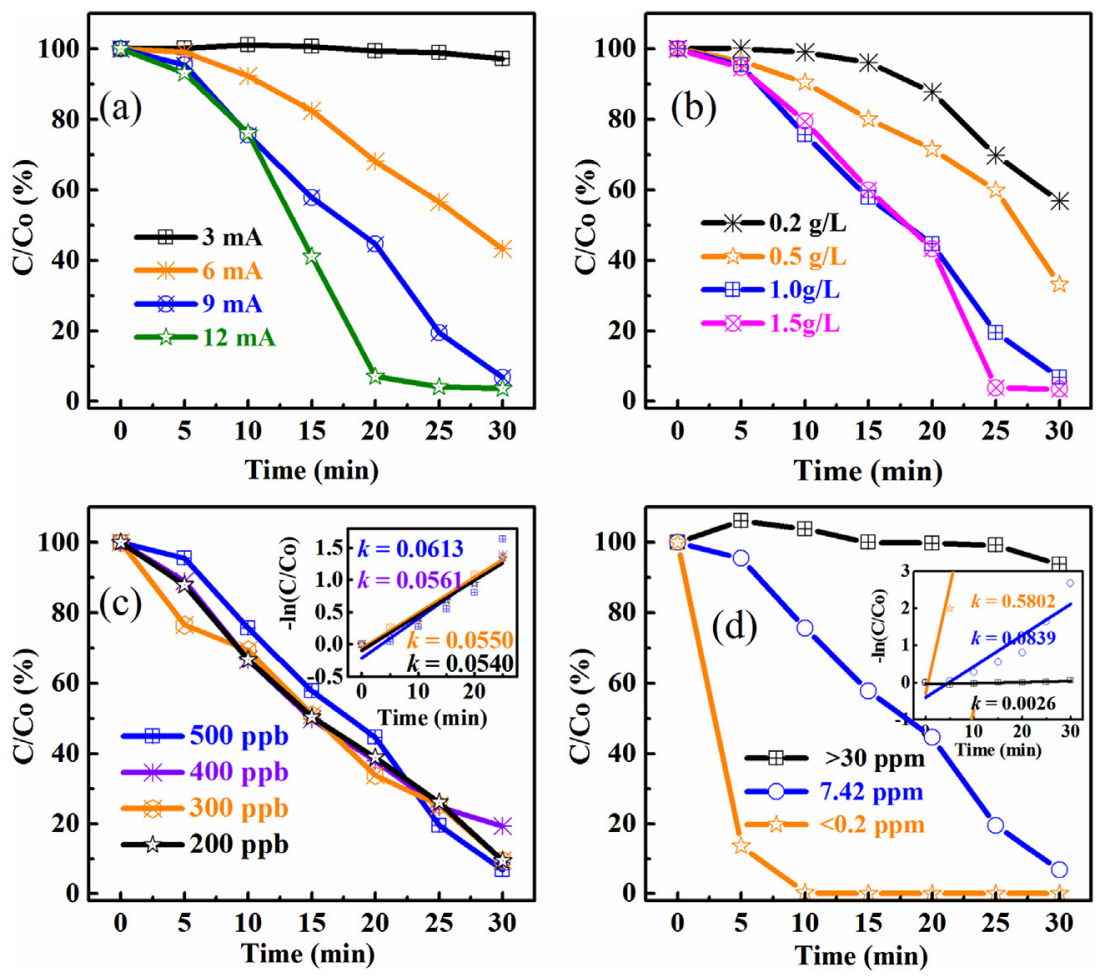

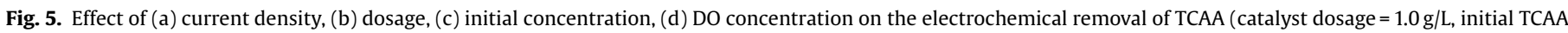

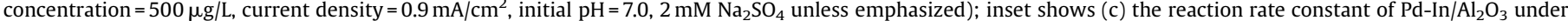
different initial TCAA concentration; (d) the reaction rate constant of Pd- $\mathrm{In} / \mathrm{Al}_{2} \mathrm{O}_{3}$ under different DO concentration.

\subsection{Proposed mechanisms of TCAA electroreduction on $\mathrm{Pd}-\mathrm{In} / \mathrm{Al}_{2} \mathrm{O}_{3}$}

The adsorption efficiency of TCAA by different catalysts was tested without electricity. No TCAA was adsorbed by $\mathrm{Al}_{2} \mathrm{O}_{3}$ and In/ $\mathrm{Al}_{2} \mathrm{O}_{3}$, and $3.0 \%$ and $2.3 \%$ of TCAA could be adsorbed by $\mathrm{Pd} / \mathrm{Al}_{2} \mathrm{O}_{3}$ and $\mathrm{Pd}-\mathrm{In} / \mathrm{Al}_{2} \mathrm{O}_{3}$ respectively (shown in Fig. S7). This result agreed with the zeta potential analysis (Fig. S4), where all the catalysts were positively charged and differed slightly at neutral $\mathrm{pH}$, but the potentials still followed the order $\mathrm{Al}_{2} \mathrm{O}_{3}<\mathrm{Pd}-\mathrm{In} / \mathrm{Al}_{2} \mathrm{O}_{3}<\mathrm{Pd} / \mathrm{Al}_{2} \mathrm{O}_{3}$. DCAA and MCAA adsorption by Pd-In/ $/ \mathrm{Al}_{2} \mathrm{O}_{3}$ was also detected. As shown in Fig. S8, no adsorption of DCAA and MCAA was observed in the 30 min batch experiment. After adding $0.9 \mathrm{~mA} / \mathrm{cm}^{2}$ current density, the TCAA was dechlorinated to DCAA or further to MCAA (Pd-In $/ \mathrm{Al}_{2} \mathrm{O}_{3}$ only, Fig. 4). However, a decrease in the summed concentration of MCAA, DCAA and TCAA along the batch experiments was detected for all the catalysts. For instance, the sum of MCAA (16\%), DCAA (42\%) and TCAA (6\%) accounted for $64 \%$ of the total CAAs at $30 \mathrm{~min}$ for Pd-In $/ \mathrm{Al}_{2} \mathrm{O}_{3}$, and since little of the CAAs could be adsorbed by $\mathrm{Pd}-\mathrm{In} / \mathrm{Al}_{2} \mathrm{O}_{3}$, the decrease of CAA concentration was due to the formation of other intermediates like $\mathrm{Cl}_{2} \dot{\mathrm{C} C O O H}$ and $\mathrm{Cl} \dot{C} \mathrm{HCOOH}$.

As TCAA could be electroreduced both by electrons and atomic $\mathrm{H}^{*}[43,44]$, the electroreduction mechanism of TCAA reduction by $\mathrm{Pd}-\mathrm{In} / \mathrm{Al}_{2} \mathrm{O}_{3}$ was investigated further. As Fig. 6(a) shows, the nine characteristic peaks of DMPO-H for atomic $\mathrm{H}^{*}$ [39] were detected, and the peak intensities followed the order Pd-In $/ \mathrm{Al}_{2} \mathrm{O}_{3}>\mathrm{Pd} / \mathrm{Al}_{2} \mathrm{O}_{3}$, while no such signal was detected when $\mathrm{Al}_{2} \mathrm{O}_{3}$ or no catalyst was used. This result confirmed the formation of atomic $\mathrm{H}^{*}$ in the TCAA electroreduction process in the three-dimension electrochemistry system using Pd-based catalysts as the particle electrode. The atomic $\mathrm{H}^{*}$ reduction of TCAA could be further enhanced by introducing In into Pd-based catalysts, further confirming that a synergistic effect between Pd and In occurred in the catalyst. In addition, scavenger experiments using Tert-BuOH to quench atomic $\mathrm{H}^{*}$ were carried out to further study the TCAA reduction process (shown in Fig. 6(b) and (c)). Blending Tert-BuOH (10 mM) into the TCAA reduction system inhibited the TCAA removal significantly. While the TCAA removal rate was $69.0 \%$ and $80.5 \%$ for $\mathrm{Pd} / \mathrm{Al}_{2} \mathrm{O}_{3}$ and $\mathrm{Pd}-\mathrm{In} / \mathrm{Al}_{2} \mathrm{O}_{3}$ at $25 \mathrm{~min}$ respectively without Tert$\mathrm{BuOH}$, the electroreduction efficiency decreased by $49.2 \%$ and $51.2 \%$ for $\mathrm{Pd} / \mathrm{Al}_{2} \mathrm{O}_{3}$ and $\mathrm{Pd}-\mathrm{In} / \mathrm{Al}_{2} \mathrm{O}_{3}$ respectively, accounting for nearly $2 / 3$ (71.3\% and $63.6 \%$ respectively) of TCAA removal without Tert-BuOH. Meanwhile, $16.7 \%$ inhibition was also detected for the control experiment (no particle electrodes). It can be speculated that the indirect atomic $\mathrm{H}^{*}$ process played a more dominant role than direct electron transfer in TCAA reduction by $\mathrm{Pd}-\mathrm{In} / \mathrm{Al}_{2} \mathrm{O}_{3}$ catalysts, and was found to be more prominent for $\mathrm{Pd} / \mathrm{Al}_{2} \mathrm{O}_{3}$. As introducing In into Pd-based catalysts could enhance the atomic $\mathrm{H}^{*}$ formation, this may explain why the TCAA removal efficiency was higher for $\mathrm{Pd}-\mathrm{In} / \mathrm{Al}_{2} \mathrm{O}_{3}$ than $\mathrm{Pd} / \mathrm{Al}_{2} \mathrm{O}_{3}$. Comparatively, $28.7 \%$ of TCAA could be reduced by $\mathrm{Pd} / \mathrm{Al}_{2} \mathrm{O}_{3}$ after atomic $\mathrm{H}^{*}$ was inhibited, lower than the value of $36.4 \%$ for $\mathrm{Pd}-\mathrm{In} / \mathrm{Al}_{2} \mathrm{O}_{3}$. That is to say, the direct electron reduction of TCAA was enhanced after In addition, indicating that the direct electron transfer was also promoted by the introduction of In into the Pd-based catalyst.

Furthermore, we investigated the intermediates and final products of the electroreduction of TCAA by $\mathrm{Pd}-\mathrm{In} / \mathrm{Al}_{2} \mathrm{O}_{3}$ after elimination of DO from the system, since $\mathrm{DO}$ is a strong competitor for TCAA, which would hinder both the direct electron transfer and indirect atomic $\mathrm{H}^{*}$ process for the electroreduction of TCAA as discussed above. As shown in Fig. 6(d), TCAA decreased rapidly while DCAA as the dechlorination intermediate increased initially, and then decreased slightly along the course of reaction; meanwhile the MCAA concentration increased along with the reduction of TCAA. As only DCAA was formed without the Pd-In catalyst (Fig. 4), the detected MCAA was formed via the indirect 

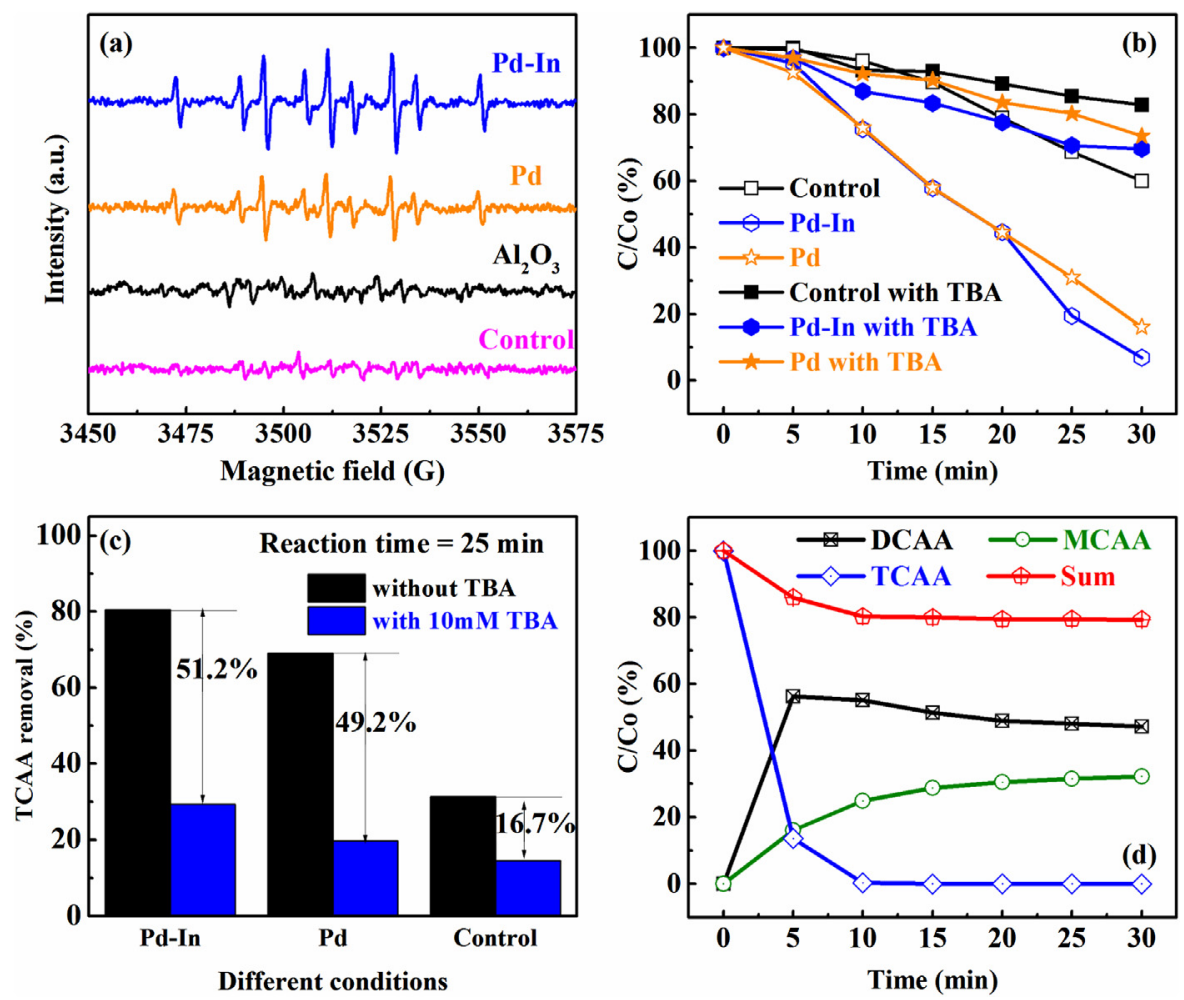

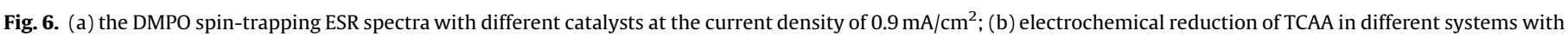

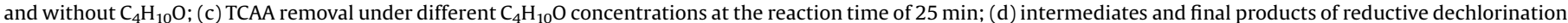

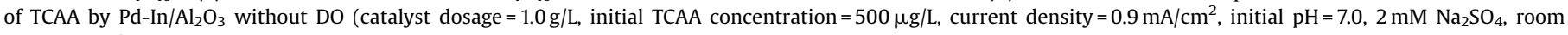
temperature).

atomic $\mathrm{H}^{*}$ function, while DCAA could also be formed via direct electron transfer. As shown in the schematic diagram (Fig. 7), the direct electroreduction may follow the pathway:

$$
\mathrm{Cl}_{2} \dot{\mathrm{C}} \mathrm{COOH}+\mathrm{H}^{+}+e^{-} \rightarrow \mathrm{Cl}_{2} \mathrm{CHCOOH}
$$

$$
\mathrm{Cl}_{3} \mathrm{CCOOH}+e^{-} \rightarrow \mathrm{Cl}_{2} \dot{\mathrm{CCOOH}}+\mathrm{Cl}^{-}
$$

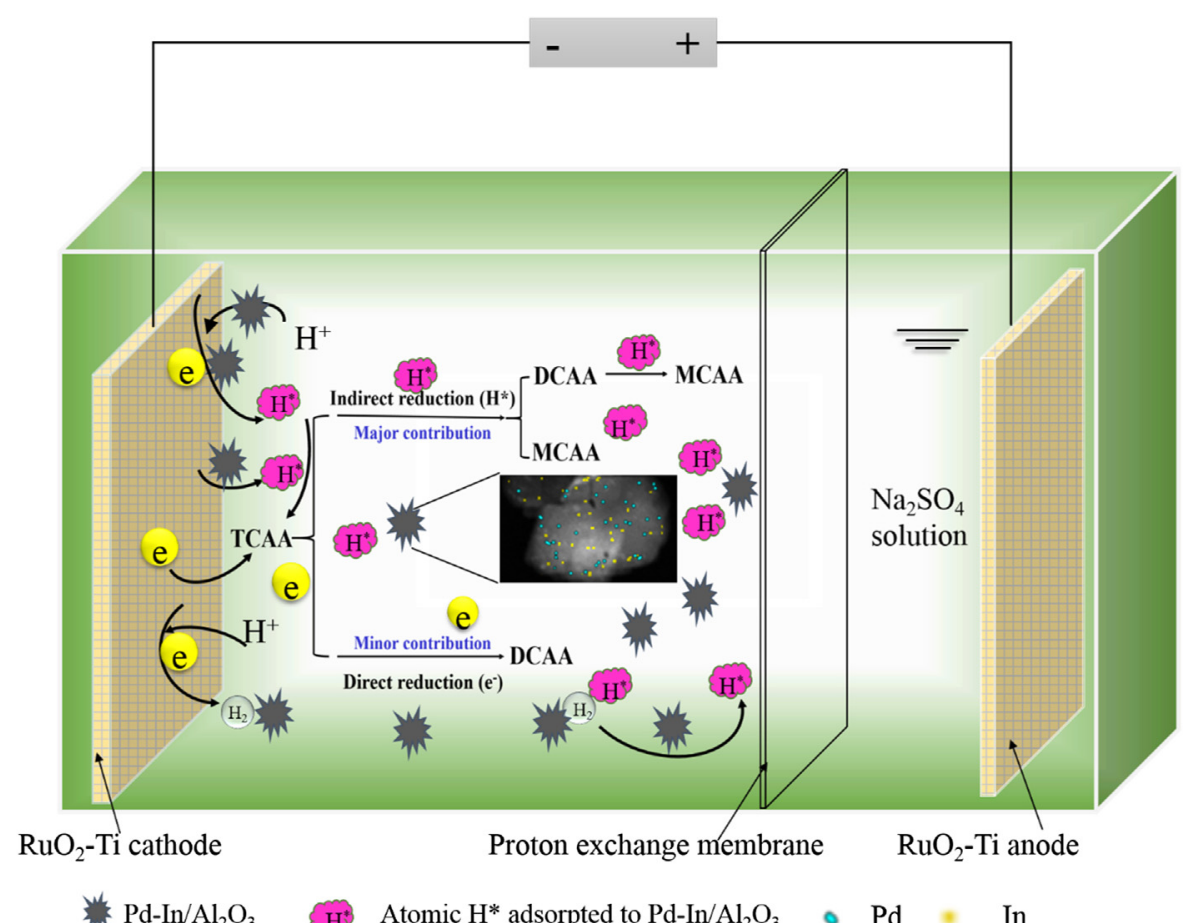

$\mathrm{Pd}-\mathrm{In} / \mathrm{Al}_{2} \mathrm{O}_{3} \quad \mathrm{H}^{*}$ Atomic $\mathrm{H}^{*}$ adsorpted to $\mathrm{Pd}-\mathrm{In} / \mathrm{Al}_{2} \mathrm{O}_{3}$ ○ $\mathrm{Pd}$ * In

Fig. 7. Schematic diagram: reaction mechanism for TCAA reduction over $\mathrm{Pd}-\mathrm{In} / \mathrm{Al}_{2} \mathrm{O}_{3}$. 
While the indirect electroreduction of TCAA by Pd-In $/ \mathrm{Al}_{2} \mathrm{O}_{3}$ can be described as:

In $\sim P d+H^{+}+e^{-} \rightarrow I n \sim P d H^{*}$

$\mathrm{Cl}_{3} \mathrm{CCOOH}^{*}+\mathrm{In} \sim \mathrm{PdH}^{*} \rightarrow \mathrm{Cl}_{2} \mathrm{CHCOOH}+\mathrm{Cl}^{-}$

$\mathrm{Cl}_{2} \mathrm{CCOOH}^{*}+\mathrm{In} \sim \mathrm{PdH}^{*} \rightarrow \mathrm{ClCH}_{2} \mathrm{COOH}+\mathrm{Cl}^{-}$

$\mathrm{Cl}_{3} \mathrm{CCOOH}^{*}+2 \mathrm{In} \sim \mathrm{PdH}^{*} \rightarrow \mathrm{ClCH}_{2} \mathrm{COOH}+2 \mathrm{Cl}^{-}$

The indirect atomic $\mathrm{H}^{*}$ played a major contribution to TCAA reduction, while direct electron transfer had a minor impact on TCAA removal by $\mathrm{Pd}-\mathrm{In} / \mathrm{Al}_{2} \mathrm{O}_{3}$.

\section{Conclusion}

In conclusion, $\mathrm{Pd}-\mathrm{In} / \mathrm{Al}_{2} \mathrm{O}_{3}$ was proven to have the highest reduction efficiency in the electrochemical reduction of TCAA in the three-dimensional electrochemical reactor, and was able to reuse in the catalyst process. The reduction process followed pseudo-first-order kinetics. Physical and chemical characterization analyses indicated that after In addition, metallic Pd existed in a more electron-rich state, which was beneficial for atomic $\mathrm{H}^{*}$ formation for the Pd-In $/ \mathrm{Al}_{2} \mathrm{O}_{3}$ catalyst, and the formation of Pd-In bimetallic alloy also had a positive effect on TCAA removal. The synergistic effect of Pd and In enhanced both the direct electron transfer and indirect atomic $\mathrm{H}^{*}$ function for TCAA reduction, and the enhanced indirect atomic $\mathrm{H}^{*}$ process played a major contribution to TCAA removal. While DCAA cannot be converted using the $\mathrm{Pd} / \mathrm{Al}_{2} \mathrm{O}_{3}$ catalyst, MCAA was further produced when using Pd-In $/ \mathrm{Al}_{2} \mathrm{O}_{3}$ under the same experimental conditions.

\section{Acknowledgements}

This work was supported by the National Natural Science Foundation of China (Nos. 51478455, 51438011) and National Science Fund for Distinguished Young Scholars of China (51225805).

\section{Appendix A. Supplementary data}

Supplementary data associated with this article can be found, in
the online version, at http://dx.doi.org/10.1016/j. electacta.2017.02.071.

\section{References}

[1] E. Malliarou, C. Collins, N. Graham, M.J. Nieuwenhuijsen, Haloacetic acids in drinking water in the United Kingdom, Water Res. 39 (2005) 2722-2730.

[2] J.G. Pressman, S.D. Richardson, T.F. Speth, R.J. Miltner, M.G. Narotsky, I.I.I.E.S. Hunter, G.E. Rice, L.K. Teuschler, A. McDonald, S. Parvez, S.W. Krasner, H.S. Weinberg, A.B. McKague, C.J. Parrett, N. Bodin, R. Chinn, C.-F.T. Lee, J.E. Simmons, Concentration, chlorination, and chemical analysis of drinking water for disinfection byproduct mixtures health effects research: U.S. EPA's four lab study, Environ. Sci. Technol. 44 (2010) 7184-7192.

[3] H. Zhou, X.J. Zhang, Occurrence of haloacetic acids in drinking water in certain cities of China, Biomed. Environ. Sci. 17 (2004) 299-308.

[4] G. Hua, J. Kim, D.A. Reckhow, Disinfection byproduct formation from lignin precursors, Water Res. 63 (2014) 285-295.

[5] M.J. Cardador, M. Gallego, Haloacetic acids in swimming pools: swimmer and worker exposure, Environ. Sci. Technol. 45 (2011) 5783-5790.

[6] B.M. Mcrae, T.M. Lapara, R.M. Hozalski, Biodegradation of haloacetic acids by bacterial enrichment cultures, Chemosphere 55 (2004) 915-925.

[7] A. Matilainen, M. Sillanpää, Removal of natural organic matter from drinking water by advanced oxidation processes, Chemosphere 80 (2010) 351-365.

[8] B. Zhao, X. Wang, H. Shang, X. Li, W. Li, J. Li, W. Xia, L. Zhou, C. Zhao, Degradation of trichloroacetic acid with an efficient Fenton assisted $\mathrm{TiO}_{2}$ photocatalytic hybrid process: reaction kinetics, byproducts and mechanism, Chem. Eng. J. 289 (2016) 319-329.

[9] J. Zhou, K. Wu, W. Wang, Y. Han, Z. Xu, H. Wan, S. Zheng, D. Zhu, Simultaneous removal of monochloroacetic acid and bromate by liquid phase catalytic hydrogenation over Pd/Ce $\mathrm{Cr}_{1-\mathrm{z}} \mathrm{Zr}_{\mathrm{x}} \mathrm{O}_{2}$, Appl. Catal. B. Environ. 162 (2015) 85-92.

[10] J. Zhou, Y. Han, W. Wang, Z. Xu, H. Wan, D. Yin, S. Zheng, D. Zhu, Reductive removal of chloroacetic acids by catalytic hydrodechlorination over $\mathrm{Pd} / \mathrm{ZrO}_{2}$ catalysts, Appl. Catal. B. Environ. 134-135 (2013) 222-230.

[11] L. Yu-Ping, C. Hong-Bin, Z. Yi, Reductive dehalogenation of haloacetic acids by hemoglobin-loaded carbon nanotube electrode, Water Res. 41 (2007) 197205.

[12] G.V. Korshin, M.D. Jensen, Electrochemical reduction of haloacetic acids and exploration of their removal by electrochemical treatment, Electrochim. Acta. 47 (2001) 747-751.

[13] A. Li, X. Zhao, Y. Hou, H. Liu, L. Wu, J. Qu, The electrocatalytic dechlorination of chloroacetic acids at electrodeposited Pd/Fe-modified carbon paper electrode, Appl. Catal. B. Environ. 111-112 (2012) 628-635.

[14] X. Zhao, A. Li, R. Mao, H. Liu, J. Qu, Electrochemical removal of haloacetic acids in a three-dimensional electrochemical reactor with Pd-GAC particles as fixed filler and Pd-modified carbon paper as cathode, Water Res. 51 (2014) 134-143.

[15] R. Mao, N. Li, H. Lan, X. Zhao, H. Liu, J. Qu, M. Sun, Dechlorination of trichloroacetic acid using a noble metal-free graphene-Cu foam electrode via direct cathodic reduction and atomic H*, Environ. Sci. Technol. 50 (2016) 3829-3837.

[16] B.P. Chaplin, M. Reinhard, W.F. Schneider, C. Schuth, J.R. Shapley, T.J. Strathmann, C.J. Werth, Critical review of Pd-based catalytic treatment of priority contaminants in water, Environ Sci Technol 46 (2012) 3655-3670.

[17] H. Choi, S.R. Al-Abed, S. Agarwal, D.D. Dionysiou, Synthesis of reactive nano-Fe Pd bimetallic system-impregnated activated carbon for the simultaneous adsorption and dechlorination of PCBs, Chem. Mater. 20 (2008) 3649-3655.

[18] D. Fang, W. Li, J. Zhao, S. Liu, X. Ma, J. Xu, C. Xia, Catalytic hydrodechlorination of 4-chlorophenol over a series of $\mathrm{Pd}-\mathrm{Cu} / \mathrm{gamma}-\mathrm{Al}_{2} \mathrm{O}_{3}$ bimetallic catalysts, $\mathrm{Rsc}$ Adv. 4 (2014) 59204-59210.

[19] I. Witońska, A. Królak, S. Karski, Bi modified Pd/support $\left(\mathrm{SiO}_{2} \mathrm{Al}_{2} \mathrm{O}_{3}\right)$ catalysts for hydrodechlorination of 2, 4-dichlorophenol, J. Mol. Catal. A. Chem. 331 (2010) 21-28.

[20] N. Toshima, M. Harada, Y. Yamazaki, K. Asakura, Catalytic activity and structural analysis of polymer-protected gold-palladium bimetallic clusters prepared by the simultaneous reduction of hydrogen tetrachloroaurate and palladium dichloride, J. Phys. Chem. 96 (1992) 9927-9933.

[21] J.A. Rodriguez, M. Kuhn, Interaction of zinc with transition-metal surfaces: electronic and chemical perturbations induced by bimetallic bonding, J. Phys. Chem. 100 (1996) 381-389.

[22] R.C. Budhani, A. Banerjee, T.C. Goel, K.L. Chopra, XPS study of glassy $\mathrm{Pd}_{80} \mathrm{Ge}_{20}$, J. Non-Cryst. Solid. 55 (1983) 93-102.

[23] E.P. Alves Rocha, F.B. Passos, F.C. Peixoto, Modeling of hydrogenation of nitrate in water on $\mathrm{Pd}-\mathrm{Sn} / \mathrm{Al}_{2} \mathrm{O}_{3}$ Catalyst: estimation of microkinetic parameters and transport phenomena properties, Ind. Eng. Chem. Res. 53 (2014) 8726-8734.

[24] R. Gavagnin, L. Biasetto, F. Pinna, G. Strukul, Nitrate removal in drinking waters: the effect of tin oxides in the catalytic hydrogenation of nitrate by $\mathrm{Pd}$ $\mathrm{SnO}_{2}$ catalysts, Appl. Catal. B. Environ. 38 (2002) 91-99.

[25] I. Witońska, S. Karski, J. Rogowski, N. Krawczyk, The influence of interaction between palladium and indium on the activity of $\mathrm{Pd}-\mathrm{In} / \mathrm{Al}_{2} \mathrm{O}_{3}$ catalysts in reduction of nitrates and nitrites, J. Mol. Catal. A. Chem. 287 (2008) 87-94.

[26] M.G. Davie, K. Shih, F.A. Pacheco, J.O. Leckie, M. Reinhard, Palladium-indium catalyzed reduction of n-nitrosodimethylamine: indium as a promoter metal, Environ. Sci. Technol. 42 (2008) 3040-3046.

[27] H.E. Swanson, T. E, Standard X-ray diffraction powder patterns, National Bureau of Standards (U.S.), 1953.

[28] H. Chen, Z. Xu, H. Wan, J. Zheng, D. Yin, S. Zheng, Aqueous bromate reduction by catalytic hydrogenation over $\mathrm{Pd} / \mathrm{Al}_{2} \mathrm{O}_{3}$ catalysts, Appl. Catal. B. Environ. 96 (2010) 307-313.

[29] I.R. Harris, M. Norman, A.W. Bryant, A study of some palladium-indium platinum-indium and platinum-tin alloys, J.the Less Common Metals. 16 (1968) 427-440.

[30] K. Takemura, H. Fujihisa, High-pressure structural phase transition in indium, Phys. Rev. B. Solid State. 47 (1993) 8465-8470.

[31] A.K.-V. Alexander, V. Naumkin, Stephen W. Gaarenstroom, Cedric J. Powell NIST X-ray photoelectron spectroscopy database, NIST Standard Reference Database 20, (2000) http://srdata.nist.gov/xps/Default.aspx.

[32] T. Hirano, Y. Ozawa, T. Sekido, T. Ogino, T. Miyao, S. Naito, The role of additives in the catalytic reduction of $\mathrm{NO}$ by $\mathrm{CO}$ over $\mathrm{Pd}-\mathrm{In} / \mathrm{SiO} \mathrm{O}_{2}$ and $\mathrm{Pd}-\mathrm{Pb} / \mathrm{SiO}_{2}$ catalysts, Appl. Catal. A. Gen. 320 (2007) 91-97.

[33] I.A. Witońska, M.J. Walock, P. Dziugan, S. Karski, A.V. Stanishevsky, The structure of $\mathrm{Pd}-\mathrm{M}$ supported catalysts used in the hydrogen transfer reactions ( $\mathrm{M}=\mathrm{In}, \mathrm{Bi}$ and Te), Appl. Surf. Sci. 273 (2013) 330-342.

[34] F.A. Marchesini, S. Irusta, C. Querini, E. Miró, Spectroscopic and catalytic characterization of $\mathrm{Pd}-\mathrm{In}$ and $\mathrm{Pt}-\mathrm{In}$ supported on $\mathrm{Al}_{2} \mathrm{O}_{3}$ and $\mathrm{SiO}_{2}$, active catalysts for nitrate hydrogenation, Appl. Catal. A. Gen. 348 (2008) 60-70.

[35] J. Zhao, W. Li, D. Fang, Effect of indium-modified palladium catalysts on the hydrodechlorination of 4-chlorophenol, Rsc Adv. 5 (2015) 42861-42868.

[36] F.A. Marchesini, L.B. Gutierrez, C.A. Querini, E.E. Miró, Pt, In and Pd, In catalysts for the hydrogenation of nitrates and nitrites in water. FTIR characterization and reaction studies, Chem. Eng. J. 159 (2010) 203-211. 
[37] H. Lan, R. Mao, Y. Tong, Y. Liu, H. Liu, X. An, R. Liu, Enhanced electroreductive removal of bromate by a supported Pd-In bimetallic catalyst: kinetics and mechanism investigation, Environ. Sci. Technol. 50 (2016) 11872-11878.

[38] X. Wang, P. Ning, H. Liu, J. Ma, Dechlorination of chloroacetic acids by Pd/Fe nanoparticles: Effect of drying method on metallic activity and the parameter optimization, Appl. Catal. B. Environ. 94 (2010) 55-63.

[39] R. Mao, X. Zhao, H. Lan, H. Liu, J. Qu, Graphene-modified Pd/C cathode and Pd/ GAC particles for enhanced electrocatalytic removal of bromate in a

continuous three-dimensional electrochemical reactor, Water Res. 77 (2015) $1-12$.

[40] R. Mao, X. Zhao, J. Qu, Electrochemical reduction of bromate by a Pd modified carbon fiber electrode: kinetics and mechanism, Electrochim. Acta. 132 (2014) $151-157$.
[41] J. Lipkowski, P.N. Ross, Electrocatalysis, Wiley-VCH, New York, 1998.

[42] W. Xie, S. Yuan, X. Mao, W. Hu, P. Liao, M. Tong, A.N. Alshawabkeh, Electrocatalytic activity of $\mathrm{Pd}$-loaded $\mathrm{Ti} / \mathrm{TiO}_{2}$ nanotubes cathode for TCE reduction in groundwater, Water Res. 47 (2013) 3573-3582.

[43] R. Mao, X. Zhao, H. Lan, H. Liu, J. Qu, Efficient electrochemical reduction of bromate by a Pd/rGO/CFP electrode with low applied potentials, Appl. Catal. B. Environ. 160-161 (2014) 179-187.

[44] J. Farrell, N. Melitas, M. Kason, T. Li, Electrochemical and column investigation of iron-mediated reductive dechlorination of trichloroethylene and perchloroethylene, Environ. Sci. Technol. 34 (2000) 2549-2556. 